\title{
The Co-operative Model as a Means of Stakeholder Management: An EXPloratory QuAlitative AnAlysis
}

\author{
Darrell Hammond and John Luiz \\ Graduate School of Business, University of Cape Town \\ Accepted: September 2016
}

\begin{abstract}
The South African economy has for some time been characterised by high unemployment, income inequality and a skills mismatch, all of which have contributed to conflict between business, government and labour. The co-operative model of stakeholder management is examined as a possible mitigating organisational form in this high-conflict environment. International experience indicates some success with co-operative models but they are not easy to implement effectively and face severe obstacles. Trust and knowledge sharing are critical for enabling a co-operative model of stakeholder management, which requires strong governance and adherence to strict rules. The model must balance the tension between optimisation of governance structures and responsiveness to members' needs. Furthermore, support from social and political institutions is necessary. We find barriers to scalability which manifest in the lack of depth of business skills, negative perception of the co-operative model by external stakeholders, government ambivalence, and a lack of willingness on the part of workers to co-operate for mutual benefit.
\end{abstract}

Key words: co-operatives, stakeholder management, social contracts

JEL: J54, 50, L23

\section{Introduction}

The problem of poverty, unemployment and inequality in South Africa has resulted in an environment of rising tensions where the lack of a social contract between business, government and labour has become increasingly apparent (see Luiz, 2014, 2016). The conflict in the labour market came most starkly to the fore during the tragic Marikana killings in 2012. As one widow from the community directly affected by the incident states, "I blame the mine, the police, and the government because they are the ones who control this country" (Alexander, Lekgowa, Mmope, Sinwell, \& Xezwi, 2013:7). The collective bargaining process that was once useful appears to have become fragmented and may have outlived its purpose. Business is progressively being viewed as a major cause of social and economic problems and companies are perceived as prospering at the expense of the community (Porter \& Kramer, 2011). The main contributor to the failure is an outdated approach to value creation that focuses on short-term financial performance and ignores wider stakeholders, thereby affecting long-term sustainability (Martin, 2009). There is thus an apparent need for a new model of stakeholder management in a highly conflictual environment.

A challenge in the South African labour market is how to empower a significant labour force which is largely unskilled and for which demand is waning. Some initiatives which corporates have tried to introduce have been unsuccessful, due in part to low levels of education and to structural shifts in the economy. Calls for higher wages do not address these problems and some would argue that higher wages would be economically unsustainable and would lead to higher unemployment. Interventions to improve skills and then to reward workers for their increased contribution may provide an alternative, sustainable solution in certain cases. This context forms the backdrop to our study and explains why there is a renewed focus on alternative organisational forms such as co-operatives. While such co-operatives may not impact directly on this macroenvironment, they may be viable options under particular conditions.

The co-operative model is unique in that it is typically applied where the workforce relies on lower skill sets and in areas which are considered economically marginal. This type of model has been used successfully in countries like Spain and Italy but has been less successful in South 
Africa. It may be necessary to re-invent the co-operative model to turn it into one that recognises South African realities - a hybrid model which combines traditional capitalist models with new shared values and co-operative principles. The purpose of this research is to evaluate the stakeholder literature with emphasis on the co-operative model within an environment of social and political conflict to determine whether the co-operative model is viable on a larger scale in South Africa. South African interest in co-operatives received a boost during 2015 as a result of a backlash against the previous decade of outsourcing non-core activities in both the public and the private spheres. For example, as a result of the \#Feesmustfall movement, universities were put under pressure to return to insourcing activities which they had been outsourcing and many universities undertook to investigate various options for doing so, including that of worker co-operatives (see http://mg.co.za/article/2015-10-15-wits-mulls-co-ops-to-end-staff-woes). This research is exploratory in nature and relies on a qualitative approach using four case studies. The paper is structured as follows: The next section presents a literature review on co-operative models and outlines factors that contribute to their success or failure. Thereafter we discuss the research methodology, followed by the presentation and discussion of our results. Finally, we conclude with a conceptual framework.

\section{Literature review}

Freeman (1984) defines the stakeholders of an organisation as any group or individual without whose support the organisation would not exist. An individual or group qualifies as a stakeholder if it affects or is affected by the organisation's objectives (Freeman, 1984), and therefore has a legitimate interest in the activities of the organisation (Donaldson \& Preston, 1995). Stakeholder theory contends that each stakeholder, whether an individual or a group, should be able to influence decision-makers in the business (Jones, 1995). Effective management requires attention to be given to all relevant stakeholders and the failure to obtain buy-in from all key stakeholders may result in the failure of the organisation (Donaldson \& Preston, 1995; Sautter \& Leisen, 1999).

The traditional view is that managers have an obligation to increase the value of equity for shareholders in the firm. In contrast, the stakeholder view argues that there are other role players such as government, unions, and social, trade and political groupings, whose interests need to be considered. The operation of firms in society is becoming more complex and it is apparent that a new framework is required to manage stakeholders' needs (Turnbull, 1997). Although there have been numerous conceptual, theoretical and empirical studies relating to stakeholder theory, very little has been done to integrate the theory into practical process models which could be effectively implemented by the firms (Preble, 2005; Roloff, 2008).

In co-operatives there is a more natural disposition towards managing stakeholders (Gijselinckx, 2009) as ownership rights and control are usually assigned to a single stakeholder category. The concept of the co-operative recognises the need for a change in the structure of the traditionally capitalist economic model and possible political mobilisation (Lele, 1981). It attempts to find a balance between economic and socio-political power in order to benefit those who are often marginalised by traditional models.

\subsection{Overview of the co-operative model}

In 1844, The Rochdale Pioneers, consisting of 28 cotton weavers in England, got together and formed a co-operative society and formulated several principles on which to conduct business. This was to form the basis for the worldwide co-operative movement (Birchall, 1997). The Rochdale Pioneers could not afford the high cost of food, and accordingly opened a store which sold goods such as sugar, flour and butter to their members at more affordable prices. The cooperative was seen as a means of combating the impact of industrial capitalism, or an embryo of socialism within a capitalist economy (Philip, 2003). Since then there has been a growth not only in the number of co-operatives but also in the models and structures on which they are based and the purposes they serve. They come in various forms, including non-monetary, retail, social, consumer, worker, and business and employment co-operatives. 
Mazzarol, Simmons \& Mamouni Limnios (2011) developed a conceptual three-level framework, consisting of the system, co-operative and members, to help explain co-operative structures and the nature of the problems faced. This framework, which is shown in Figure 1, demonstrates four key inputs and two outputs. On the input side: social co-operation is driven by the community that is being motivated; this community is able to mobilise, and has skills, money and resources. Government policy can have a significant impact on co-operative development through its policies in relation to market regulation, corporate governance and tax legislation, as well as social and economic policies. Industry structure relates to Porter's five-force model, which includes level of competitiveness within the industry, power of buyers and sellers, and threats from new entrants and substitutes. Environmental impacts can be significantly affected by access to land and water, disease, climate change, and drought or floods. The outputs of the model are economic capital, measured by the creation of wealth, jobs and assets, and social capital, made up of trust, reciprocity and networks.

Figure 1

Co-operative conceptual framework

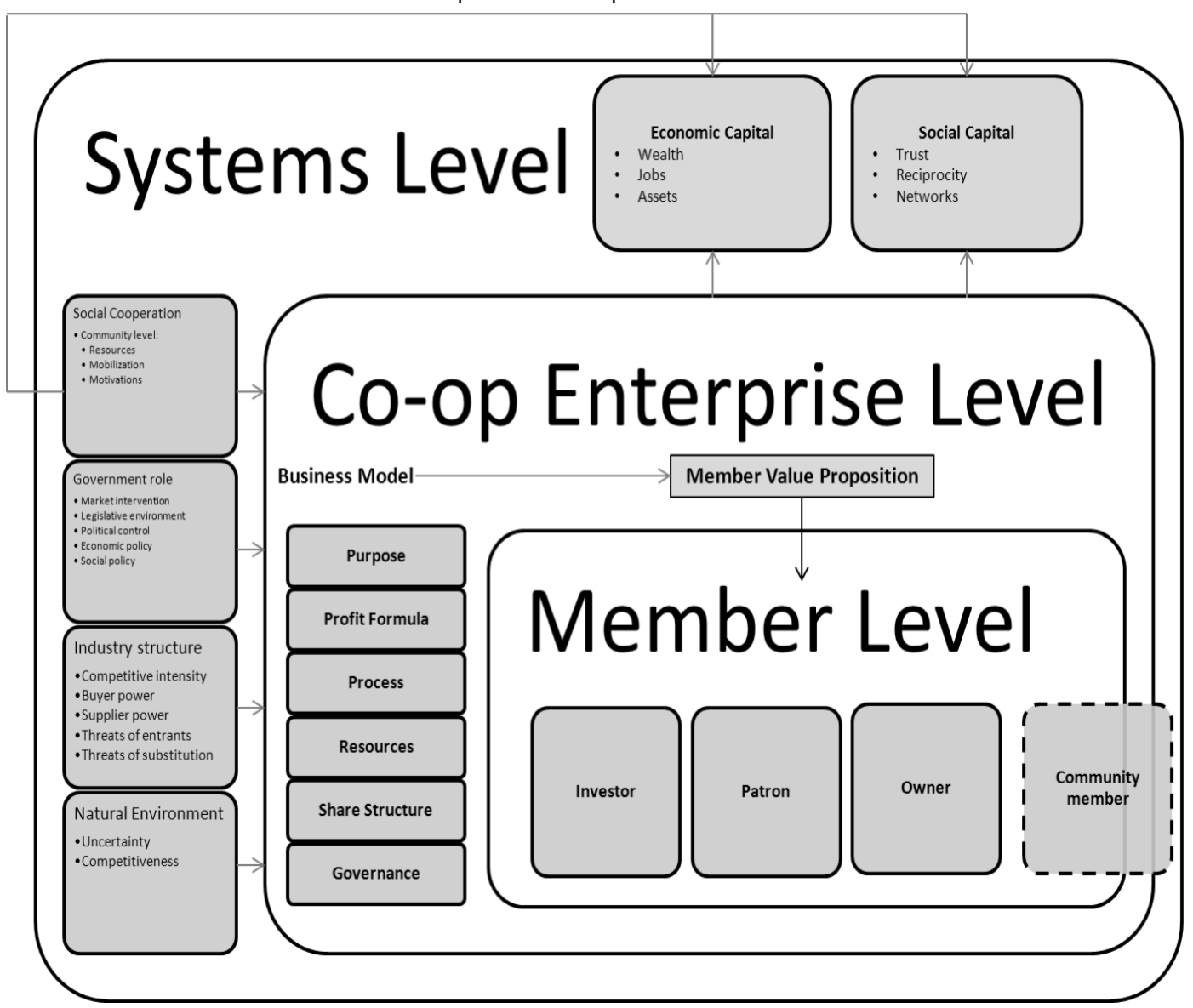

Source: Mazzarol et al. (2011)

There is no general consensus on the factors that explain success and failure of the co-operative model. Simmons and Birchall (2008) indicate that the success factors vary significantly between types of co-operative, country and time period. However, the literature shows that success factors can be split between internal and external factors and these are evaluated in more detail below. 


\subsubsection{Internal success factors}

Trust: A core value of the co-operative model lies in the lowering of transaction costs through self-governance and trust which has been found to be fundamental to co-operative development and its sustainability (Cook, 1995; Birchall, 1997; Sabatini, Modena \& Tortia, 2014). In the absence of trust, self-governance and co-operation often fail. In a highly conflictual environment there are high levels of mistrust, and co-operatives may provide the means to reverse this mistrust, but attempts to introduce self-help initiatives without unity often fail (Parnell, 2003). Before a cooperative model can be introduced, the trust-building process needs to have commenced (Parnell, 2001). However, once the process has started, co-operatives can accelerate the building of trust because of the mutual benefit to all members; this necessitates a sense of community and willingness for members to engage (Mazzarol, 2012).

Knowledge sharing: In order to function successfully, a co-operative is a business which requires people who are skilled in business processes and knowledgeable about markets. Selfregulation requires the support of a reliable and fast information network so as to ensure that all members have access to information in a transparent manner (Turnbull, 1997; Borgen, 2004). A well-defined stakeholder ownership and control structure improves performance significantly by providing more reliable information via multiple channels, and thereby reducing transaction costs and increasing operational efficiency (Turnbull, 1997). Birchall (2011) suggests that co-operative failure, due to disengagement on the part of members, is the result of a lack of education rather than a problem with motivation, and investing in the education of members is crucial to cooperative success. When co-operatives in more developed countries are compared with those in less developed countries, the case of Mondragon ${ }^{1}$ in the former group suggests that although the community was poor owing to unemployment, they were educated and each member was therefore able to contribute towards the growth of the co-operative. In contrast, the communities in the latter group are often uneducated, and the challenge therefore lies in enabling these communities to improve their skills in order for the co-operative to be successful. As the co-operative grows larger, the flow of information becomes slower. A lack of information and institutional failure may lead to risk and uncertainty within the co-operative (Borda-Rodriguez \& Vicari, 2013). Greater information flow can be achieved through decentralisation and the creation of smaller business units, which then leads to additional channels of communication. This feeds into the networking strength of co-operatives.

Governance: Governance plays a pivotal role in motivating members to engage by managing conflict between members' interests within a well-defined framework (Philip, 2003; Cook, 1995; Mazzarol, 2012; Dyer \& Singh, 1998). The choice of governance structure depends on the type of relationship and perceived risk for each member entering into the agreement. Ultimately, the structure chosen needs to minimise transaction costs and maximise efficiency (Dyer \& Singh, 1998; Nilsson, 1999). Parties can either rely on third parties to enforce agreements, or else selfenforce them. The co-operative achieves a self-regulating governance mechanism through a set of guiding principles which every member is required to adhere to. The management structure is based on participation, democracy and transparency.

As in a traditional organisation which has stockholders and is managed by a management team and board, at the core of the co-operative there is a board or governing body. There is normally a chain of command and actions are carried out through delegation from top management to the shop floor (Lutz, 1997). The principle underlying the governance role of the governing board of a co-operative is to service the interests of co-operative members. Although many co-operatives start with a single board, sustainability is achieved through multiple or compound boards. With the introduction of a compound board, outside strategic stakeholders are able to get involved and provide impartial guidance in the interests of the co-operative. A compound board has the advantages of reducing corruption, increasing the number of individuals participating in control and minimising information distortion and the overloading of single board members. 
Incentive to invest: Motivation for members to engage is driven by the ability of the cooperative to satisfy the needs of the member as a consumer of the co-operative products, member of the community, owner and investor. It is therefore necessary to look at the factors which motivate and hinder cooperation and engagement on the part of members, such as the horizon problem, where a worker's permissible claim to the co-operative assets is recognised for a shorter period than the life of the asset, and hence there is little incentive to invest capital in the cooperative (Novkovic, 2008; Porter \& Scully, 1987). This relates back to the governance structure already discussed and the importance of a well-defined framework. On retirement or exit from the co-operative, the worker is only entitled to withdraw the capital in instalments. This effectively solves the problem where capital in the co-operative is indivisible and provides motivation for workers to invest in the co-operative. The instalment only policy on retirement means that there is a large capital pool from which the co-operative can draw funds for growth.

\subsubsection{External success factors}

Networking: One of the strengths of a co-operative lies in co-operation with external stakeholders, suppliers and customers (Birchall \& Simmons, 2004). Co-operation is based on self-regulation, which can be achieved through sufficiently wide stakeholder participation, including with the broader community. From a network perspective, this provides a means of scaling up operations by building more extensive networks through small co-operative clusters (Birchall \& Simmons, 2004; Porter \& Kramer, 2011). The principle on which the development of local clusters is based is the premise that the firm's success is affected by the communities and infrastructure around it (Porter \& Kramer, 2011). The term "cluster" refers to the geographical proximity of businesses, suppliers and supporting infrastructure - which includes educational institutions, utilities, the regulatory framework, market transparency, and the community. Porter and Kramer (2011) point out that clusters are crucial in driving productivity, innovation and competitiveness. However, the potential for expanding participation in networks is affected by perceptions of other network partners (Parnell, 2001) and their willingness to transact. Inside a network the interaction moves away from pure economic drivers to factors driven by social dynamics (Granovetter, 1992). The trend towards social dynamics suggests that building personal relationships through trust and good governance is critical in building strong networks.

Political and social institutions: Government policy is a very important factor influencing the development of co-operatives. In developed countries, co-operatives have been free of government control and have been based on the Rochdale principles of self-governance, namely one-memberone-vote with distribution of surpluses to members (Simmons \& Birchall, 2008). In contrast, the co-operatives in less developed countries were developed predominantly by governments as a means of transforming traditional economies, but they were controlled by politicians to further their own interests rather than the interests of members. This top-down approach from government policy to co-operative development in developing countries has led to the failure of co-operatives in these countries (Simmons\& Birchall, 2008). Although it plays a vital role in providing the framework and environment for the co-operative to develop, the government's involvement should not hamper the autonomy of the co-operative to function as its own entity and make its own decisions. The state's role should be to provide political, legal and administrative frameworks. The state also plays a critical role in providing access to resources and to new markets (Awuah \& Amal, 2011). The relationship with the government and outside stakeholders is therefore beneficial and critical as long as they do not interfere with the management of the co-operative.

\section{Research methodology}

An inductive, qualitative method of analysis was used as the method of inquiry as this was deemed most appropriate for a study that focused on understanding social phenomena within the context of the participants' perspectives and experiences (Merriam, 2002). Furthermore, because the qualitative method is more responsive and flexible it lends itself better to contextual interpretation 
than quantitative research does. The main data collection method was through interviews with respondents at government organisations and selected co-operatives. A semi-structured questionnaire was used in the interviews and the researchers used field observations and data to provide additional insights and put the results in context. The research instrument is provided in Appendix A. The interviews were recorded, with permission, for later transcription and evaluation.

In selecting which co-operatives to include in the research, an analysis of the South African cooperatives was carried out. The age data of these co-operatives as of September 2013, according to the Department of Trade and Industry (DTI), are shown in Table 1.

The data indicate a considerable increase in the number of new co-operatives registered in the preceding five years. However, the data also reflect relatively poor performance by co-operative organisations and a high failure rate, since only 260 co-operatives have survived for more than ten years. We have therefore included a tiered selection of co-operatives: one organisation which has been in existence for one year, another for five years, and two for over twenty years. The reason for this was to identify possible characteristics that could contribute towards scalability and sustainability of the co-operative model. A total of 27 interviews were conducted across the four co-operative organisations. Case studies have three possible aims: to provide descriptions, test theory, or generate theory (Eisenhardt \& Graebner, 2007). Our aim was to conduct an explorative, descriptive study and thus an age-defined purposive sample was deemed appropriate. The 27 interviews included the managers of each co-operative (4), the Director of the National Development Agency (within the Department of Social Development, tasked with contributing towards poverty eradication by engaging civil society organisations and capacitating them to empower communities and also with exercising oversight over co-operatives), and 22 workers/members distributed across each of the co-operatives.

Table 1

Co-operatives in South Africa

\begin{tabular}{|l|c|}
\hline \multicolumn{1}{|c|}{ Co-operative age (years) } & Count \\
\hline$<5$ & 73000 \\
\hline $5-10$ & 3300 \\
\hline $10-20$ & 160 \\
\hline $20+$ & 100 \\
\hline
\end{tabular}

The researchers employed an auditing trail to ensure that complete records were kept throughout all phases of the research. These records included field notes, research processes, recordings, interview questionnaires and transcripts, and data analysis files and methods. A thematic analysis was performed to analyse the data and provide a comparison between the literature and field research and thereby gain insight into similarities and differences. Initially the focus was on reviewing the data to become familiar with them and ensure accuracy. Thereafter, initial coding, based on the key themes identified, was undertaken. An iterative process of coding was employed until the rich themes emerged which allowed us to tell the exploratory story below.

A multimethod framework was used to gather data. The framework included interviews, observations by researchers at the actual sites, and the use of secondary documents among which were co-operative reports and official government documents. Furthermore, we ensured that we heard multiple voices, including those of the managers and workers/members as well as representatives from government as part of our interviewed sample.

This research was conducted in accordance with the ethical requirements of the university the authors are attached to and was cleared by the university Ethics Committee. This required that the research would not have any significant ethical consequences in terms of physical, psychological, social, legal, economic, or other risks to participants. No participants were below the age of eighteen years. The research was conducted with full consent from all parties involved and participation was voluntary. The purpose of the study was clearly communicated to respondents, who were under no obligation to provide information and could withdraw at any time. 


\section{Results and discussion}

\subsection{Background of sampled co-operatives}

\subsubsection{Diepsloot worker co-operative}

Diepsloot Worker Co-operative (DWC) is located in Diepsloot township, north of Johannesburg and was started in September 2012. The co-operative employs 32 members from the Diepsloot community, most of whom are women, and produces bags made from plastic shopping packets, PVC, and leather offcuts. Their value proposition lies in producing high quality products. However, most of the items are very simple to manufacture.

The co-operative operates differently from the conventional co-operative model, in that members do not own and control all the means of production. Instead, the co-operative focuses on core skills of workers while functions such as legal, financial, marketing and general administration are outsourced. Members earn a monthly wage based on output and a share of the profits which are paid out annually, in accordance with the co-operative legislation. The external support received by the co-operative included a start-up loan, as well as the outsourced support, although the co-operative pays market rates for these support services.

\subsubsection{Pretorium Trust}

Pretorium Trust (PT) was formed in 1938 by a group of government employees, in order to reduce the price of household goods through collective purchasing. Commission was charged on purchases made from the co-operative. The commission was re-invested in the co-operative and the surplus paid out annually as dividends to members. The co-operative is based in Pretoria and has 23 employees servicing 23000 members. The current General Manager has been in this post since 1966 and the majority of the 23 employees have been with the organisation for over 20 years. Employees have the choice of becoming members, but are not obliged to do so. The cooperative remains a buying association, with the primary income obtained through rebate agreements with selected retailers. The rebate typically ranges between two percent from larger retailers up to five percent from smaller retailers. Additional revenue streams include short-term insurance, loans and vehicle finance. A fee of R10 is required for every new application, after which a compulsory monthly fee of R15 is charged, which is used to fund working capital. Each member is also required to deposit an amount of twice his/her monthly credit limit, which helps protect against member defaults.

\subsubsection{Coastal farmers' co-operative limited}

Coastal Farmers' Co-operative (Coastals) was started in 1946 by a group of farmers in KwaZuluNatal. Their goal was to reduce the price of fertiliser, diesel, fuel and other farming commodities for themselves and other members through economies of scale. The co-operative is currently the largest purchaser of farming commodities in the KwaZulu-Natal coastal belt and has increased its product range significantly since inception. The Head Office is located in Mount Edgecombe, north of Durban, and employs approximately 150 people. The current General Manager (GM) has been at the helm since 2005, before which the previous GM headed the co-operative for 39 years. Its membership consists of approximately 1400 predominantly sugar, banana and citrus farmers. All employees of the co-operative are non-members, unless they are farmers, in which case they have the opportunity to become members. The board of directors are all farmers and members of the co-operative. According to the 2013 financial statements, the revenue was R240 million.

\subsubsection{Ujimabakwena shoemaking co-operative}

Ujimabakwena Shoemaking Co-operative was a merger of two shoe-making co-operatives, one of which was formed by a group of retrenched workers from a shoe factory. The co-operative has 17 members and 23 non-members. Non-members are employed on a non-permanent basis according to the requirements of seasonal demand. The co-operative supplies its shoes through the Department of 
Social Services (DSS) in Gauteng, which subsidises 40000 learners from disadvantaged communities. The DSS supports the initiative on the understanding that the levels of quality, price and service are not compromised. In addition, the co-operative supports other co-operatives with its skills, while also receiving support from these other co-operatives. Additional business skills and financial support are provided by government and certain private sector companies.

\subsection{The drivers of the co-operative model in a high-conflict environment}

The relationship between business, government and labour internationally has gone through periods in which models of stakeholder management have been questioned. In South Africa this relationship has been problematic, given its history of inequality and political instability, which has led to extremely volatile labour relations. The co-operative model is said to be more effective because it is able to strengthen relationships between stakeholders (Birchall \& Simmons, 2004). Respondents were asked about what they thought the drivers of the co-operative model were and broadly speaking it was contended that these were building trust and knowledge sharing. Table 2 identifies the key emergent themes which arose relating to trust.

Table 2

Pertinent quotes and themes relating to trust

\begin{tabular}{|c|c|c|}
\hline Theme & Quote & Source \\
\hline \multirow{5}{*}{$\begin{array}{l}\text { Trust is essential if } \\
\text { the co-operative is } \\
\text { to succeed }\end{array}$} & If trust is lacking, it would not work...we are dealing with people's money. & Manager: Pretorium Trust \\
\hline & The co-op requires even more ethics than standard business. & Manager: Pretorium Trust \\
\hline & $\begin{array}{l}\text { Trust goes with integrity. Your members must trust you. If they don't, it will } \\
\text { be like a fire spreading, and pretty soon you will be out of business. You } \\
\text { need to maintain the highest possible quality of business standards and } \\
\text { ethics for those members. If there is no integrity, you will not be trusted. }\end{array}$ & Manager: Pretorium Trust \\
\hline & They do what they say they will do. They have earned their trust. & Member: Coastals \\
\hline & $\begin{array}{l}\text { [Building trust] Open and honest and have high moral values in dealing with } \\
\text { our customers and members. }\end{array}$ & Manager: Coastals \\
\hline \multirow{8}{*}{$\begin{array}{l}\text { Transparency and } \\
\text { communication } \\
\text { fundamental to } \\
\text { building trust }\end{array}$} & $\begin{array}{l}\text { Very important...trusting each other...but to be trusted by others, } \\
\text { transparency should prevail...each and everything should be in black and } \\
\text { white. }\end{array}$ & Manager: Ujimabakwena \\
\hline & Communication and transparency are essential. & Manager: Ujimabakwena \\
\hline & Our intention is fair. We have a transparent system here. & Manager: Diepsloot \\
\hline & As and when it [conflict] arises, we intervene immediately. & Manager: Diepsloot \\
\hline & $\begin{array}{l}\text { [Dealing with conflict]. Not always aligned with the same objective. Speak to } \\
\text { that person to see if we can solve that problem. }\end{array}$ & $\begin{array}{l}\text { Manager } \\
\text { Pretorium Trust }\end{array}$ \\
\hline & $\begin{array}{l}\text { Trust that the customer member is getting a fair deal. Trust is the key } \\
\text { principle that is embedded in the DNA of the co-operative. }\end{array}$ & Manager: Coastals \\
\hline & $\begin{array}{l}\text { One of the key things which make the co-operative work, we don't just } \\
\text { instruct people...we always negotiate. As workers, they have the right to } \\
\text { say no...we always give them options. }\end{array}$ & Manager: Ujimabakwena \\
\hline & $\begin{array}{l}\text { [Relationship between workers and members] There are rules. We sit down } \\
\text { and everyone has something to say. }\end{array}$ & Worker: Ujimabakwena \\
\hline \multirow{8}{*}{$\begin{array}{l}\text { Family environment } \\
\text { and sense of } \\
\text { community to build } \\
\text { trust }\end{array}$} & $\begin{array}{l}\text { Yes, we trust everyone. When we are doing something, we teach each } \\
\text { other...we think we are going to gain more for what we are doing. }\end{array}$ & Worker: Diepsloot \\
\hline & Because it is like a family. You are working like a family. & Manager: Diepsloot \\
\hline & $\begin{array}{l}\text { Living that values system through the entire organisation from the Board to } \\
\text { the lowest level staff members. Basic principles - such as honesty, integrity } \\
\text { and responsibility. }\end{array}$ & Manager: Coastals \\
\hline & Conflict between management and staff is not there. & Manager: Pretorium Trust \\
\hline & We need to treat each other like a family. & Manager: Ujimabakwena \\
\hline & $\begin{array}{l}\text { One thing we are very strict about, we do not entertain individual conflicts. } \\
\text { Draw a line that it mustn't affect the work. }\end{array}$ & Manager: Ujimabakwena \\
\hline & $\begin{array}{l}\text { Need to foster collaboration.... and sometimes even force it. Need to } \\
\text { dialogue more. It is a function of leadership and the trust environment. }\end{array}$ & $\begin{array}{l}\text { Director: National } \\
\text { Development Agency }\end{array}$ \\
\hline & $\begin{array}{l}\text { Difficult to build trust. Culturally and demographically it is difficult to work } \\
\text { together...but it comes back to strong leadership. When we are here, we } \\
\text { are a family, we are a team. }\end{array}$ & Manager: Diepsloot \\
\hline
\end{tabular}


All respondents agreed with Cook (1995), Birchall (1997) and Sabatini et al. (2014) that trust was fundamental to the co-operative's success. But how do the co-operatives build this trust in an environment where there are high levels of mistrust? Two key themes emerged: open and honest communication, and a family environment. In order to create a family environment, the co-operatives were very cautious when selecting members and employees, which was indicative of the high levels of mistrust in the general community. This finding was more evident with the developing cooperatives because the more established co-operatives had already institutionalised the working environment. When conflict arose, it was dealt with decisively in all four co-operatives. This sentiment was confirmed by managers, workers, members and non-members alike, and this highlighted the importance of each co-operative seeking to maintain a stable, low-conflict environment. Within the co-operatives, conflict was dealt with by applying strict rules requiring members and employees to set their differences aside. If members did not accept these principles, then they were asked to leave. Pretorium Trust allowed members to join by following a standard credit approval process, but Coastals admitted only members who were farmers. However, if members defaulted or failed to meet their obligations, their membership was cancelled.

Knowledge sharing was found to be another important contributor to the success of the cooperative - a number of subthemes emerged within this theme and they are summarised in Table 3. A strong theme confirmed by all four co-operatives was the need to operate as profitable businesses (Mazzarol, 2012). However, depth of business skills was found to be lacking in the start-up co-operatives. For their co-operatives to function effectively, Ujimabakwena and Diepsloot worker co-operatives realised that there was a need to focus on their core strengths in order to build the organisations into sustainable entities. Diepsloot Worker Co-operative adapted its business model by outsourcing functions such as marketing, bookkeeping and general administration where it lacked the required skills. Ujimabakwena leveraged its links with government and outside agencies to provide training in the functions for which it had limited skills. All four co-operatives indicated a strong need for ongoing education and knowledge sharing between members and fellow workers.

Table 3

Themes related to knowledge sharing

\begin{tabular}{|c|c|c|}
\hline Theme & Quote & Source \\
\hline \multirow{4}{*}{$\begin{array}{l}\text { Depth of business } \\
\text { skills essential }\end{array}$} & $\begin{array}{l}\text { It is not the sector, it is the foundation of business development which is } \\
\text { lacking. }\end{array}$ & $\begin{array}{l}\text { Director: National } \\
\text { development agency }\end{array}$ \\
\hline & The co-operative really is business. Our product has to be world class. & Manager: Diepsloot \\
\hline & $\begin{array}{l}\text { Depth of skill is lacking in business development... Requires market } \\
\text { access, funding, skills, inclination to run business on different level. }\end{array}$ & $\begin{array}{l}\text { Director: National } \\
\text { development agency }\end{array}$ \\
\hline & $\begin{array}{l}\text { Co-op is still a business enterprise. On the one hand we are capitalistic, } \\
\text { we make profits. On the other hand we are socialistic, everything goes } \\
\text { back to the members. That is the true platform of co-ops }\end{array}$ & Manager: Pretorium Trust \\
\hline \multirow[t]{2}{*}{ Strong leadership } & $\begin{array}{l}\text { It takes a key man on the ground to get things going...it needs the key } \\
\text { management. }\end{array}$ & Manager: Diepsloot \\
\hline & I am passionate about the business. & Manager: Coastals \\
\hline \multirow[b]{2}{*}{ Focus on core skills } & We must let co-ops do what they are good at. & Director: NDA \\
\hline & $\begin{array}{l}\text { We allow members to focus on their core strength and outsource other } \\
\text { business functions. }\end{array}$ & Manager: Diepsloot \\
\hline \multirow{6}{*}{$\begin{array}{l}\text { Ongoing learning } \\
\text { fundamental to co- } \\
\text { operative development }\end{array}$} & If you have got nothing, no education, nothing is going to come from it. & Manager: Diepsloot \\
\hline & $\begin{array}{l}\text { We pay half of the studies for anyone who wants to attend a tertiary } \\
\text { institution. }\end{array}$ & Manager: Pretorium Trust \\
\hline & Whatever we have learnt from training, we take it to all the members. & Manager: Ujimabakwena \\
\hline & We discuss all the problems once a month. & Manager: Pretorium Trust \\
\hline & I teach this lady and she teaches me as well. & Worker: Ujimabakwena \\
\hline & $\begin{array}{l}\text { We take education very seriously hence most of our staff are receiving } \\
\text { both internal and external training through reputable organisations like } \\
\text { UNISA and the local Chamber of Commerce. }\end{array}$ & Manager: Coastals \\
\hline
\end{tabular}




\subsection{The role of governance in the co-operative}

Sustainable governance of a co-operative must be achieved through a self-regulating information and control system (Dyer \& Singh, 1998; Turnbull, 1997), but the governance structure needs to be balanced against the ability to meet members' needs. Respondents were asked how the cooperative met their needs as members and what incentivised them to become members. The key themes which emerged included the family working environment, learning and development, financial remuneration, and strong governance - see Table 4 .

\section{Table 4}

Motives for joining a co-operative

\begin{tabular}{|c|c|c|}
\hline Theme & Quote & Source \\
\hline \multirow{7}{*}{$\begin{array}{l}\text { Strong family } \\
\text { environment }\end{array}$} & $\begin{array}{l}\text { [Why work here] Excellent work/personal life balance. Has a family culture where } \\
\text { employees are not just a number. }\end{array}$ & Manager: Coastals \\
\hline & We are working as a family. Management, they are like parents. & Worker: Diepsloot \\
\hline & Here we are Simunye, we are 'In One'. & Worker: Diepsloot \\
\hline & Maybe less employees allows more time to respect each others' work. & $\begin{array}{l}\text { Manager: Pretorium } \\
\text { Trust }\end{array}$ \\
\hline & The people will make me stay. It doesn't matter if I don't get paid 'cos I like my job. & Manager: Diepsloot \\
\hline & $\begin{array}{l}\text { From an employee point of view the atmosphere is family oriented and therefore } \\
\text { the desire to stay over long periods of time is evident. }\end{array}$ & Manager: Coastals \\
\hline & They treat us very well. They communicate with us. & Worker: Ujimabakwena \\
\hline \multirow{5}{*}{$\begin{array}{l}\text { Balance between } \\
\text { learning and } \\
\text { financial reward }\end{array}$} & We do some different things and we learn... and we work hard to get the money. & Worker: Diepsloot \\
\hline & Providing a job and teaching us more things we didn't know. & Worker: Diepsloot \\
\hline & [Willing to accept lower salary] Definitely. & $\begin{array}{l}\text { Manager: Pretorium } \\
\text { Trust }\end{array}$ \\
\hline & I get money when working so hard...I get more experience, I can learn here. & Worker: Diepsloot \\
\hline & $\begin{array}{l}\text { [What motivates you to work here] The other members... and the bonus. } 60 \% \\
\text { environment, } 40 \% \text { bonus. }\end{array}$ & $\begin{array}{l}\text { Manager: Pretorium } \\
\text { Trust }\end{array}$ \\
\hline \multirow{5}{*}{$\begin{array}{l}\text { Knowledge } \\
\text { sharing }\end{array}$} & If have work, I know, I see. & Manager: Diepsloot \\
\hline & $\begin{array}{l}\text { I teach myself and I teach others. I like here...I learn more...if I am on the other } \\
\text { side [other company] I didn't learn more. Now I'm just improve...my dreams start } \\
\text { to open...I like my job...I am proud of my work. }\end{array}$ & Manager: Diepsloot \\
\hline & $\begin{array}{l}\text { I choose this co-operative because it makes me great, it grows me, it's everything } \\
\text { to me, so I am proud. I don't care about money. }\end{array}$ & Worker: Diepsloot \\
\hline & It is not about the money, it is about the satisfaction about what you have done. & Worker: Ujimabakwena \\
\hline & [What do you value most?]. To get more knowledge. & Worker: Diepsloot \\
\hline \multirow{3}{*}{$\begin{array}{l}\text { Need to alleviate } \\
\text { poverty }\end{array}$} & $\begin{array}{l}\text { Co-op born out of need to alleviate poverty. Social enterprise trying to compete as } \\
\text { a business. A hybrid model of social entrepreneurship. }\end{array}$ & $\begin{array}{l}\text { Manager: Pretorium } \\
\text { Trust }\end{array}$ \\
\hline & $\begin{array}{l}\text { Surely I want to live a better life... being an owner makes me } 100 \text { percent } \\
\text { responsible. }\end{array}$ & $\begin{array}{l}\text { Manager: } \\
\text { Ujimabakwena }\end{array}$ \\
\hline & I am able to put food on the table. & Worker: Diepsloot \\
\hline \multirow{8}{*}{$\begin{array}{l}\text { Strong } \\
\text { governance } \\
\text { essential }\end{array}$} & $\begin{array}{l}\text { We have } 5 \text { managers at the top... before taking decisions, we go back to } \\
\text { members to discuss... We share the responsibilities as management. }\end{array}$ & $\begin{array}{l}\text { Manager: } \\
\text { Ujimabakwena }\end{array}$ \\
\hline & We have got one vision. & $\begin{array}{l}\text { Manager: } \\
\text { Ujimabakwena }\end{array}$ \\
\hline & $\begin{array}{l}\text { As much as we are all equal, there is leadership in this co-operative...it is almost } \\
\text { a process of holding hands. }\end{array}$ & Manager: Diepsloot \\
\hline & As we employ people we put in laws...creates discipline. & $\begin{array}{l}\text { Manager: } \\
\text { Ujimabakwena }\end{array}$ \\
\hline & $\begin{array}{l}\text { We cannot all lead, but we must choose the leaders who can lead us to the right } \\
\text { direction. }\end{array}$ & $\begin{array}{l}\text { Manager: } \\
\text { Ujimabakwena }\end{array}$ \\
\hline & We used shared governance. & Worker: Ujimabakwena \\
\hline & $\begin{array}{l}\text { [Balancing governance with workers' needs] It's not easy...all the rules given to } \\
\text { the employees make it easier... we don't just tell them, we give them the reason. }\end{array}$ & Worker: Ujimabakwena \\
\hline & $\begin{array}{l}\text { Good governance structures... are the simple rules and regulations that are set } \\
\text { with monitoring systems that are restorative and fair. }\end{array}$ & Manager: Coastals \\
\hline
\end{tabular}

The role of governance was found to be instrumental in the co-operative's development and ongoing success. The governance structures of all four co-operatives are shown in Figure 2. All 
four structures were found to follow a normal chain of command where actions are carried out through delegation from top management to the shop floor.

Figure 2

Organograms of co-operatives

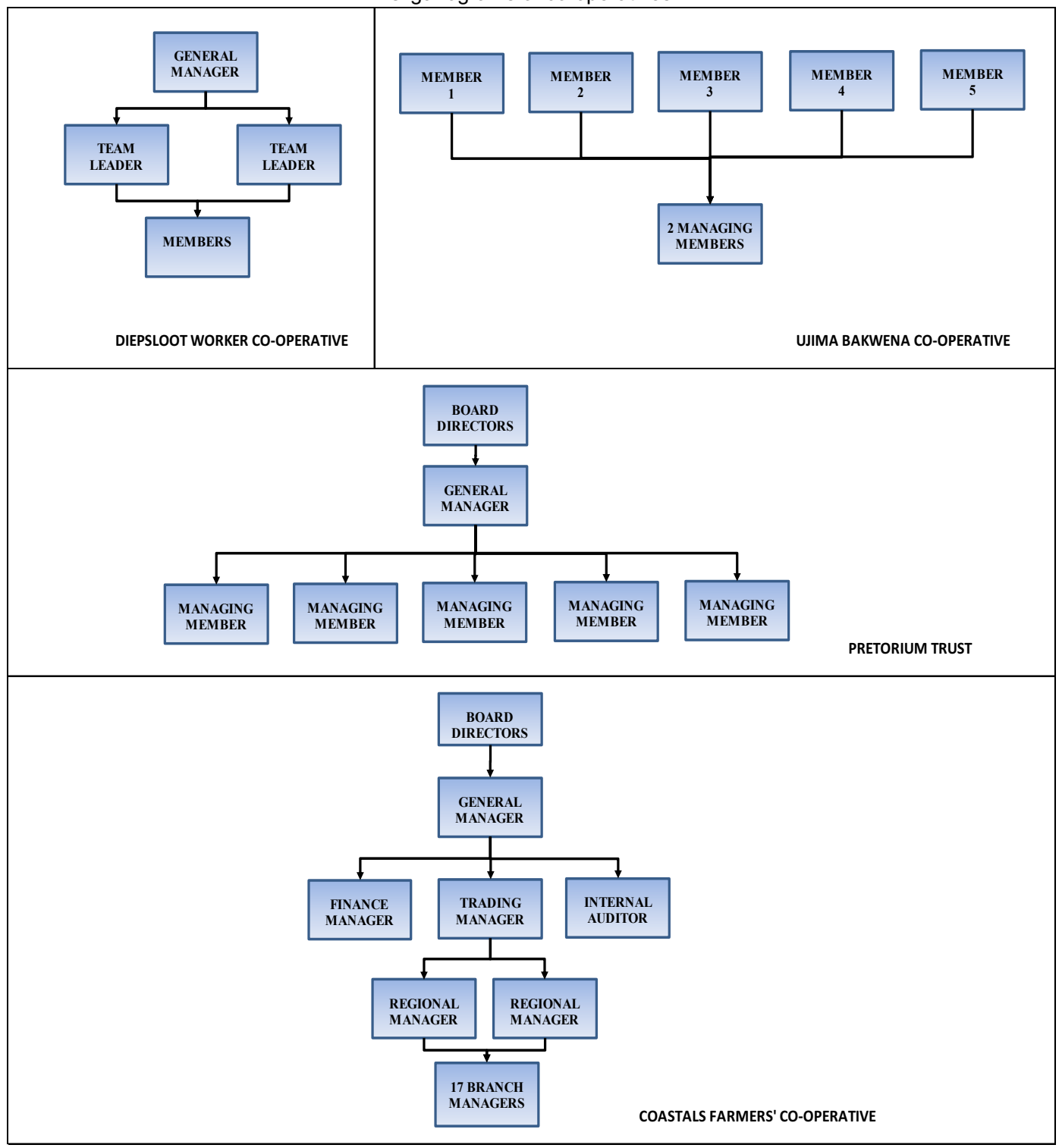

Diepsloot workers' co-operative: The General Manager (GM) and two team leaders manage the co-operative. Together, they are able to adequately and quickly address the needs of the member workforce through communication of a single vision and strong leadership.

Ujimabakwena shoemaking co-operative: The co-operative has 17 members and 23 nonmembers and governance is shared between five members. The operation is based within a single facility and members and non-members are all treated equally. The five-member board appoints two members as Operations Managers and they oversee daily operations. However, members and non-members are regularly updated and consulted on all matters, and the management also freely communicates with workers as and when the need arises. 
Pretorium Trust: The co-operative has a Board of Directors and a GM. The organisation is located in a single building and has 23 working members servicing 23000 member customers. More effective communication is achieved via the use of a well-structured IT system. However, the GM maintains a close relationship with all employees, to which the fact that most employees have been with the company for over 20 years bears testimony. The GM has also been in his post since 1966 and maintains an open-door policy.

Coastals farmers' co-operative: The co-operative is headed by a board of directors, each with his/her own ward or region. The allocation of directors to wards improves communication with members: 'Directors are members of the co-operative and are farmers in their respective areas. This allows for easier communication with members (customers) and directors are aware of the importance of communication with members.' This structure has shown its effectiveness in meeting the needs of the members and demonstrated sustainability through its existence over the past 67 years.

The research indicates that as the co-operatives become larger, the governance structures need to adapt to include boards of governors in order to service the interests of the members better. Although the larger co-operatives have a well-defined governance structure in place, there is a certain degree of informal management in order to engage with members.

Building relationships with suppliers, customers and other co-operatives is an essential component of the successful operation of a co-operative (Birchall \& Simmons, 2004). Respondents were asked what they thought was required to build and maintain these relationships, and what impeded their progress. The dominant themes which emerged related to governance, relationship management and trust - see Table 5.

Table 5

Themes in building external networks

\begin{tabular}{|c|c|c|}
\hline Theme & Quote & Source \\
\hline \multirow{2}{*}{$\begin{array}{l}\text { Mistrust of co- } \\
\text { operatives by } \\
\text { external } \\
\text { stakeholders }\end{array}$} & $\begin{array}{l}\text { A large corporate said: "We do not deal with co-operatives. The co-operative } \\
\text { members don't trust each other. Inherent mistrust with external stakeholders." }\end{array}$ & $\begin{array}{l}\text { Manager: Diepsloot } \\
\text { Worker }\end{array}$ \\
\hline & $\begin{array}{l}\text { Amongst our old established customers they view our organisation as high value to } \\
\text { their operation...younger entrants feel that they could achieve much better deals on } \\
\text { their own. Some perceive the co-operative as a "white man's business". }\end{array}$ & Manager: Coastals \\
\hline \multirow{5}{*}{$\begin{array}{l}\text { Move towards } \\
\text { social dynamics }\end{array}$} & $\begin{array}{l}\text { Our members are our customers. Our members are in a long-term business. } \\
\text { Managing relationships is crucial. }\end{array}$ & Manager: Coastals \\
\hline & $\begin{array}{l}\text { Generally, co-operatives have a good perception. They are not seen as "capitalist" } \\
\text { and vehicles for exploiting customers or employees. }\end{array}$ & Manager: Coastals \\
\hline & $\begin{array}{l}\text { Communication. Building trust between parties. Aligning parties with } \\
\text { similar/common goals. }\end{array}$ & Manager: Coastals \\
\hline & We share our challenges with other co-operatives. & $\begin{array}{l}\text { Manager: } \\
\text { Ujimabakwena }\end{array}$ \\
\hline & $\begin{array}{l}\text { Although your neighbour is a fellow farmer, he is not viewed as a competitor (unlike } \\
\text { how it works in other businesses). This allows for sharing of information, best } \\
\text { practice, co-operation with security, purchasing etc. }\end{array}$ & Manager: Coastals \\
\hline \multirow{4}{*}{$\begin{array}{l}\text { Governance crucial } \\
\text { for building strong } \\
\text { networks and } \\
\text { relationships }\end{array}$} & $\begin{array}{l}\text { Internal governance is extremely important to developing external relationships. } \\
\text { The first order was sold on the quality and the promise of delivery. The second } \\
\text { order was sold on the track record of delivery and the quality. }\end{array}$ & Manager: Diepsloot \\
\hline & $\begin{array}{l}\text { [Good governance] Integrity, honesty and fairness as part of the culture of the co- } \\
\text { op which is visible to members/ customers, staff and third parties e.g. suppliers. }\end{array}$ & Manager: Coastals \\
\hline & $\begin{array}{l}\text { Integrity is not negotiable in our dealings with members, suppliers and other } \\
\text { stakeholders. }\end{array}$ & Manager: Coastals \\
\hline & Credibility and reputation come with good governance. & Member: Coastals \\
\hline \multirow{3}{*}{$\begin{array}{l}\text { Building networks } \\
\text { requires trust and } \\
\text { dedication }\end{array}$} & Building trust with customers...we get in front of them. & Manager: Diepsloot \\
\hline & I have gained trust from my suppliers...a promise is a promise. & $\begin{array}{l}\text { Manager: } \\
\text { Ujimabakwena }\end{array}$ \\
\hline & $\begin{array}{l}\text { Over the years families pass on their assets from one generation to another and the } \\
\text { trust is measured by the value of our growth within our organisation; the fact that } \\
\text { the newer generations remain closely aligned with our organisation means there is } \\
\text { high value of trust. }\end{array}$ & Manager: Coastals \\
\hline
\end{tabular}


The results show that the co-operatives view governance as a critical component in developing strong relationships with suppliers, customers and other co-operatives, and that integrity, honesty and delivering on a promise are the enablers of strengthening these relationships. However, a significant barrier to developing external relationships is the inherent mistrust of co-operatives (Parnell, 2001). This was powerfully illustrated in the following statements: 'We do not deal with co-operatives. The co-operative members don't trust each other', and the co-operative is a 'white man's business'. A further contributor to mistrust of the co-operative model relates to the high failure rate of co-operatives; businesses do not want to risk dealing with entities which have a high perceived likelihood of failing.

\subsection{The role of social and political institutions in co-operative development}

In socially conflicted environments, the co-operative model has shown success in tapping into local experience and knowledge (Parnell, 2001). We therefore examine the extent to which external support is required for the successful development of the co-operative and the results broadly indicate that support from both political and social institutions is important - see Table 6 .

Table 6

Themes for support from social and political institutions in co-operative development

\begin{tabular}{|c|c|c|}
\hline Theme & Quote & Source \\
\hline \multirow{5}{*}{$\begin{array}{l}\text { Government, private } \\
\text { enterprise and other } \\
\text { co-operatives providing } \\
\text { support to start-up co- } \\
\text { operatives }\end{array}$} & Government invested R200 m over 5 years. & NDA \\
\hline & [a large company] put up starting capital of R500 000. & Manager: Diepsloot \\
\hline & $\begin{array}{l}\text { We didn't have a clue on how to run a business. We need to consult outside } \\
\text { people who will tell us whether we are taking the right decisions. }\end{array}$ & $\begin{array}{l}\text { Manager: } \\
\text { Ujimabakwena }\end{array}$ \\
\hline & $\begin{array}{l}\text { We got skills [to manage company] through Business Skills South Africa, } \\
\text { education from service providers through support from DTI. }\end{array}$ & $\begin{array}{l}\text { Manager: } \\
\text { Ujimabakwena }\end{array}$ \\
\hline & We are using other co-operatives to provide training for us. & $\begin{array}{l}\text { Manager: } \\
\text { Ujimabakwena }\end{array}$ \\
\hline $\begin{array}{l}\text { Support for non-core } \\
\text { activities }\end{array}$ & $\begin{array}{l}\text { We have products, production management and sales and marketing to } \\
\text { assist these other co-operatives. Let's help the co-operative with things } \\
\text { which are not their core strength. }\end{array}$ & Manager: Diepsloot \\
\hline $\begin{array}{l}\text { Mentors crucial to } \\
\text { success }\end{array}$ & $\begin{array}{l}\text { In particular, you can tell the difference between those co-ops which have } \\
\text { had a mentor and those which have not. }\end{array}$ & NDA \\
\hline \multirow{3}{*}{$\begin{array}{l}\text { External support } \\
\text { diminishes as size of } \\
\text { co-operative increases }\end{array}$} & No government support. No support from outside agencies. & $\begin{array}{l}\text { Manager: Pretorium } \\
\text { Trust }\end{array}$ \\
\hline & We don't receive support from external agencies. & $\begin{array}{l}\text { Manager: Pretorium } \\
\text { Trust }\end{array}$ \\
\hline & [Government involvement] Minimal direct involvement & Manager: Coastals \\
\hline
\end{tabular}

There were two dominant themes which emerged from the research. The first was that in a less developed, socially conflicted environment the co-operative model requires support from political or social institutions in the early stages of development in order to succeed, but chances of obtaining the required support are inhibited by mistrust of the co-operative model and therefore support institutions are reluctant to invest. The second was that as the co-operative becomes larger and self-regulating the need for external support diminishes. In the case of Diepsloot Worker Cooperative, support was provided by private corporate institutions. This support was both financial and service-related, the latter being based on the outsourcing of critical business functions which the co-operative was not able to perform due to lack of skills. Ujimabakwena received both financial and educational support from government. This support was provided without any conditions from government, which is significant as it allowed the co-operative to remain autonomous without external interference in the governance of the co-operative. In the case of Pretorium Trust and Coastals, the co-operatives do not require support from external agencies at present and are self-regulating and self-sustaining entities. This shows that the need for support is reduced as the co-operative becomes larger. 


\section{Conclusion}

The objective of the research was to describe the co-operative model as a means of stakeholder management in a high-conflict environment such as South Africa, where there has been increased tension between business, government, and labour. The challenge lies in finding a model which empowers workers with low skills and which could mitigate highly conflictual environments.

International experience indicates some success with co-operative models but it is important to realise that they are not easy to implement effectively and face severe obstacles. Pretending that they is some sort of general panacea to the macro environment is problematic but this does not mean that they do not have a place under particular circumstances where traditional models of stakeholder management have become less effective.

On the basis of our research we argue the following as regards the conditions for successful cooperative models:

1 Trust and knowledge-sharing are critical in enabling a co-operative model of stakeholder management and this requires adherence to strict rules and strong governance.

2 The co-operative model needs to balance the tension between optimisation of governance structures and responsiveness to members' needs.

3 The ability of the co-operative to develop strong networks with external stakeholders is dependent upon strong governance and relationship management to build trust.

4 Support from social and political institutions is necessary to enable a co-operative model of stakeholder management in a less developed, high-conflict environment.

Our results are summarised in our conceptual framework, which is reflected in Figure 3. The model is made up of internal and external factors. External factors include the political and social institutions such as government, NGOs, external education and support organisations. During the early phases of co-operative development, external support structures are extremely critical for enabling success. The complexities of the kind of collective organisation that is required to run a co-operative often require initial external support, especially in environments where there is high conflict and a lack of education. Such contexts may require external facilitation to organise into a co-operative, since this would mean overcoming the challenges associated with a lack of trust or understanding around the workings and rationale of co-operatives. Independent, impartial, external institutions can facilitate the process of building a co-operative but this requires that they are trusted by all parties and are seen as being objective and without vested interests. Furthermore, in the early stages co-operatives may be especially in need of external support to develop the management acumen and market networks necessary for long-term viability. These external factors contribute towards developing governance structures and motivating factors which influence members to co-operate; such co-operation in turn feeds into the governance structure at the core of the co-operative. A strong governance structure, enabled through knowledge-sharing and trust, promotes the creation of strong networks with suppliers and customers. As the sustainability of the co-operative increases, so the need for external support is reduced.

There are, however, major barriers to the scalability of the co-operative model. Firstly, the depth of business skills within the co-operative limits the ability of the co-operative to compete in the market. Secondly, the way co-operatives are perceived by external stakeholders may significantly hinder investment and growth opportunities for the co-operative. Thirdly, the lack of alignment of government communication and policy to the co-operative model is particularly important during the early stages when the co-operative requires external support. A high-conflict environment requires a more accommodative and inclusive model, which necessitates even greater levels of open communication, knowledge-sharing and governance in order to succeed. However, the last barrier, namely the willingness of the workers or members to co-operate for mutual benefit, is closely linked to the success of this inclusive model. Where there are high levels of conflict, social unrest, unrealistic expectations regarding higher wages, or where there is a mindset of entitlement, the co-operative model may not be the appropriate solution. This becomes further 
complicated where there are high levels of ethno-linguistic fractionalisation, with this diversity making a family-like environment difficult (see Luiz, 2015). The traditional co-operative model may therefore require further adaptation to accommodate diversity in high-conflict environments and this is an important area for future research.

Figure 3

Conceptual model for co-operative success

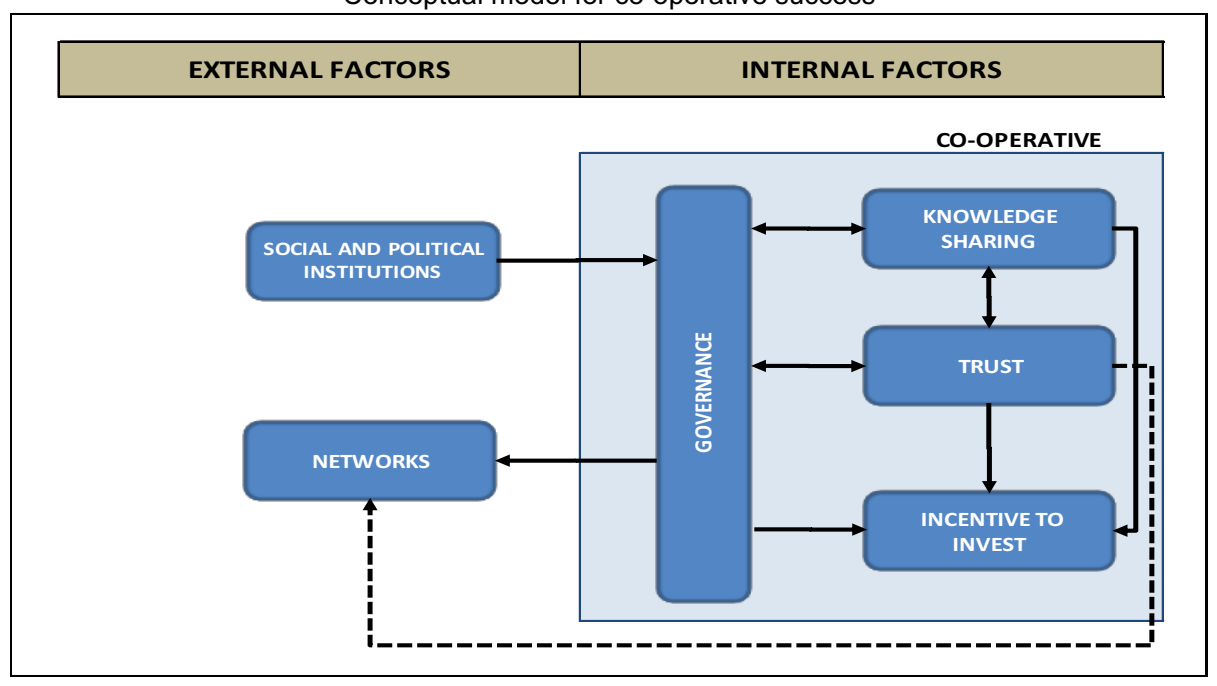

A limitation of the research is that the sample of co-operatives was small and may not be representative of worker co-operatives in high-conflict environments more generally. This limits our generalisability and our ability to understand the full diversity and heterogeneity of our population. Our research is exploratory in nature and like many qualitative studies its purpose is not to generalise but rather to provide a rich, contextualised understanding of these particular cases.

This immediately suggests possibilities for future research, which could develop more representative samples so as to extend the generalisability of the results. Alternatively, a longitudinal study of a limited number of co-operative cases would allow us to examine the way co-operatives evolve and develop over time. Furthermore, such studies would allow us to analyse how this model reacts to socio-political shocks at the macro level.

Endnote

1 Mondragon Corporation is the embodiment of the co-operative movement that began in 1956, the year that witnessed the creation of the first industrial cooperative in Mondragón in the province of Gipuzkoa, Spain. The Corporation's Mission combines the core goals of a business organisation competing in international markets with the use of democratic methods in its business organisation, the creation of jobs, the human and professional development of its workers and a pledge to development with its social environment. In terms of organisation, it is divided into four areas: Finance, Industry,

Distribution and Knowledge, and is today the foremost Basque business group and the tenth largest in Spain. See http://www.mondragon-corporation.com/eng/about-us/

\section{References}

ALEXANDER, P., LEKGOWA, T., MMOPE, B., SINWELL, L. \& XEZWI, B. 2013. Marikana: A view from the mountain and a case to answer. Johannesburg: Jacana Media.

AWUAH, G. \& AMAL, M. 2011. Impact of globalization: The ability of less developed countries' (LDCs') firms to cope with opportunities and challenges. European Business Review, 23(1):120-132.

BIRCHALL, J. 1997. The international cooperative movement. Manchester: University Press.

BIRCHALL, J. \& SIMMONS, R. 2004. What motivates members to participate in co-operative and mutual businesses? Annals of Public and Cooperative Economics, 75(3):465-495. 
BIRCHALL, J. 2011. People-centred businesses: Co-operatives, mutuals and the idea of membership. New York: Palgrave \& McMillan.

BORDA-RODRIGUEZ, A. \& VICARI, S. 2013. Understanding rural co-operative resilience: A literature review IKD Working Paper No. 64.

BORGEN, S. 2004. Rethinking incentive problems in co-operative organizations. The Journal of SocioEconomics, 33:383-393.

COOK, M. 1995. The future of U.S. agricultural cooperatives: A neo-institutional approach. American Journal of Agricultural Economics, 77:1153-1159.

DONALDSON, T. \& PRESTON, L. 1995. The stakeholder theory of the corporation: Concepts, evidence, and implications. Academy of Management Review, 20:65-91.

DYER, J. \& SINGH, H. 1998. The relational view: Cooperative strategy and sources of interorganizational competitive advantage. Academy of Management Review, 23(4):660-679.

EISENHARDT, K.M. \& GRAEBNER, M.E. 2007. Theory building from cases: Opportunities and challenges. Academy of Management Journal, 50(1):25-32.

FREEMAN, R. 1984. Strategic management: A stakeholder approach. Boston: Pitman.

GIJSELINCKX, C. 2009. Co-operative stakeholders. Who counts in co-operatives, and how? Working Papers on Social and Co-operative Entrepreneurship WP-SCE 09, 5.

GRANOVETTER, M. 1992. Problems of explanation in economic sociology: Networks and organizations: Structures, form and action. Boston: Harvard Business School Press.

JONES, T. 1995. Instrumental stakeholder theory: A synthesis of ethics and economics. The Academy of Management Review, 20:404-437.

LELE, U. 1981. Co-operatives and the poor: A comparative perspective. World Development, 9(1):55-72.

LUIZ, J.M. 2014. Social compacts for long-term inclusive economic growth in developing countries. Development in Practice, 24(2):234-244.

LUIZ, J.M. 2015. The impact of ethno-linguistic fractionalization on cultural measures: Dynamics, endogeneity and modernization. Journal of International Business Studies, 46:1080-1098.

LUIZ, J.M. 2016. The political economy of middle-income traps: Is South Africa in a long-run growth trap? The path to "bounded populism". South African Journal of Economics, 84(1):3-19.

LUTZ, M. 1997. The Mondragon co-operative complex: An application of Kantian ethics to social economics. International Journal of Social Economics, 24(12):1404-1421.

MARTIN, R. 2009. The design of business: Why design thinking is the next competitive advantage. Boston: Harvard Business Press.

MAZZAROL, T., SIMMONS, R. \& MAMOUNI LIMNIOS, E. 2011. A conceptual framework for research into co-operative enterprise. Centre for Entrepreneurial Management and Innovation Working Paper:1102. MAZZAROL, T. 2012. Guide to building strong and successful co-ops. University of Western Australia. http://www.australia2012.coop/downloads/Mazzarol_2012_Building_strong_Reslient_Sustainable_ Coops.pdf [accessed August 2013].

MERRIAM, S.B. 2002. Qualitative research in practice: Examples for discussion and analysis. California: Wiley.

NILSSON, J. 1999. Co-operative organisational models as reflections of the business environments. The Finnish Journal of Business Economics, 4(99):449-470.

NOVKOVIC, S. 2008. Defining the co-operative difference. Journal of Socio-Economics, 37(6):2168-2177. PARNELL, E. 2001. The role of cooperatives and other self-help groups in crisis resolution and socioeconomic recovery. ILO Cooperative Branch and IFP/CRISIS. Geneva.

PARNELL, E. 2003. The role for cooperatives and other self-help organizations (SHOs). In: Jobs after war: A critical challenge in the peace and reconstruction puzzle:285.

PHILIP, K. 2003. Co-operatives in South Africa: Their role in job creation and poverty reduction. Johannesburg: South African Foundation.

PORTER, M. \& KRAMER, M. 2011. The big idea: Creating shared value. Harvard Business Review, 89(1):2. 
PORTER, P. \& SCULLY, G. 1987. Economic efficiency in cooperatives. The Journal of Law and Economics, 30:409-512.

PREBLE, J. 2005. Toward a comprehensive model of stakeholder management. Business and Society Review, 110(4):407-431.

ROLOFF, J. 2008. Learning from multi-stakeholder networks: Issue focused stakeholder management. Journal of Business Ethics, 82:233-250.

SIMMONS, R. \& BIRCHALL, J. 2008. The role of co-operatives in poverty reduction: Network perspectives. Journal of Socio-economics, 37(6):2131-2140.

SABATINI, F., MODENA, F. \& TORTIA, E. 2014. Do cooperative enterprises create social trust? Small Business Economics, 42(3):621-641.

SAUTTER, E. \& LEISEN, B. 1999. Managing stakeholders: A tourism planning model. Annals of Tourism Research, 26(2):312-328.

TURNBULL, S. 1997. Stakeholder co-operation. Journal of Co-operative Studies, 29(3):18-52.

\section{Appendix A: Research instrument}

1 What is working with current relationships between labour, government and business?

2 How can the relationships between labour, government and business be improved?

3 What methods or processes are being used currently to manage internal and external stakeholders?

4 What makes the co-operative model work effectively?

5 What is the value of trust within the co-operative?

6 How does the co-operative deal with education and transfer of knowledge?

7 What does not work well in the co-operative?

8 What do you value most working in the co-operative?

9 What could be done better?

10 What determines a good governance structure?

11 How does the co-operative deal with conflict between internal stakeholders?

12 What motivates co-operation?

13 How important is the network of relationships, both internally and with external co-operatives and stakeholders?

14 How do you strengthen networks?

15 What effect does the economic climate have on the co-operative?

16 What is your perception of co-operatives in the community?

17 How does the co-operative deal with a lack of trust between members and external stakeholders?

18 How does the co-operative deal with external conflict?

19 Is there a history of political involvement or state control of co-ops?

20 What is the legal framework in existence for co-ops?

21 What role do external sources of knowledge and support play in development of the cooperative?

22 What effect does government policy have on the co-operative?

23 What is the value of the community to the co-operative?

24 What is the effect of culture on the co-operative? 